\author{
Adam KALINA ${ }^{1}$ \\ Aleksander MAZURKOW ${ }^{2}$ \\ Stanisław WARCHOL ${ }^{3}$
}

\title{
WYZNACZANIE LUZU OBWODOWEGO W ZAZĘBIENIU KÓŁ PRZEKŁADNI FALOWEJ
}

\begin{abstract}
W pracy przedstawiono metodę wyznaczania luzu obwodowego dla przyjętego zarysu ewolwentowego koła podatnego i sztywnego przekładni falowej. W pierwszej części pracy scharakteryzowano parametry geometryczne przekładni. Następnie dla współpracujących kół zębatych zdefiniowano luz obwodowy, przedstawiono założenia do modelu matematycznego wyznaczania luzu obwodowego, omówiono algorytm metody rozwiązania równań modelu matematycznego. We wnioskach zawarto wyniki badań symulacyjnych. Opracowana metoda zostanie wykorzystana w dalszych badaniach do określenia w strefie kontaktu zazębiających się kół rozkładu nacisków i odkształceń.
\end{abstract}

Słowa kluczowe: przekładnia falowa, zazębienie, koło sztywne, koło podatne, luz obwodowy

\section{Wprowadzenie}

Przekładnie falowe ze względu na specyfikę pracy stanowią dla konstruktorów złożone zagadnienie do realizacji [1]. Jednym z problemów w zapewnieniu poprawnej pracy pary zazębiających się kół: podatnego i sztywnego jest dobór geometrii wieńców wraz z odpowiadającymi im luzami. W niniejszej publikacji przedstawiono metodę wyznaczania luzu obwodowego. Do badań przyjęto koła zębate o zarysie ewolwentowym. Koło podatne ma zarys wypukły, koło sztywne natomiast - zarys wklęsły.

\section{Droga względna zęba koła podatnego}

W pierwszym etapie wyznaczania luzu obwodowego niezbędne jest ustalenie względnego położenia współpracujących wieńców koła sztywnego i podatnego. W pracy przyjęto, że wspomniane położenia określają trajektorie dwóch punktów wyznaczających oś zęba. Punkty te leżą kolejno na przecięciu osi zęba z okręgami

\footnotetext{
1 Autor do korespondencji/corresponding author: Adam Kalina, Politechnika Rzeszowska, al. Powstańców Warszawy 8, 35-959 Rzeszów, tel.: (17) 7432398, e-mail: akalina@ prz.edu.pl

2 Aleksander Mazurkow, Politechnika Rzeszowska, e-mail: almaz@ prz.edu.pl

${ }^{3}$ Stanisław Warchoł, Politechnika Rzeszowska, e-mail: warchols@prz.edu.pl
} 
stóp i głów. Dokładny opis ich wyznaczania w zależności od konstrukcji przekładni przedstawiono w pracach [2, 3]. Położenia zęba względem wrębu określa się, obracając i przesuwając punkty wyznaczające oś zęba. Wyznaczanie trajektorii omawianych punktów opisano szczegółowo w artykule [4]. Z kolei w publikacji [5] omówiono zasady modyfikacji trajektorii przemieszczania się koła podatnego przez zmianę parametru $\mathrm{w}_{0}$ - maksymalnego odkształcenia promieniowego. Na rysunku 1. pokazano jedną z możliwych do uzyskania dróg względnych położeń zęba koła podatnego przekładni falowej względem nieruchomego koła sztywnego.

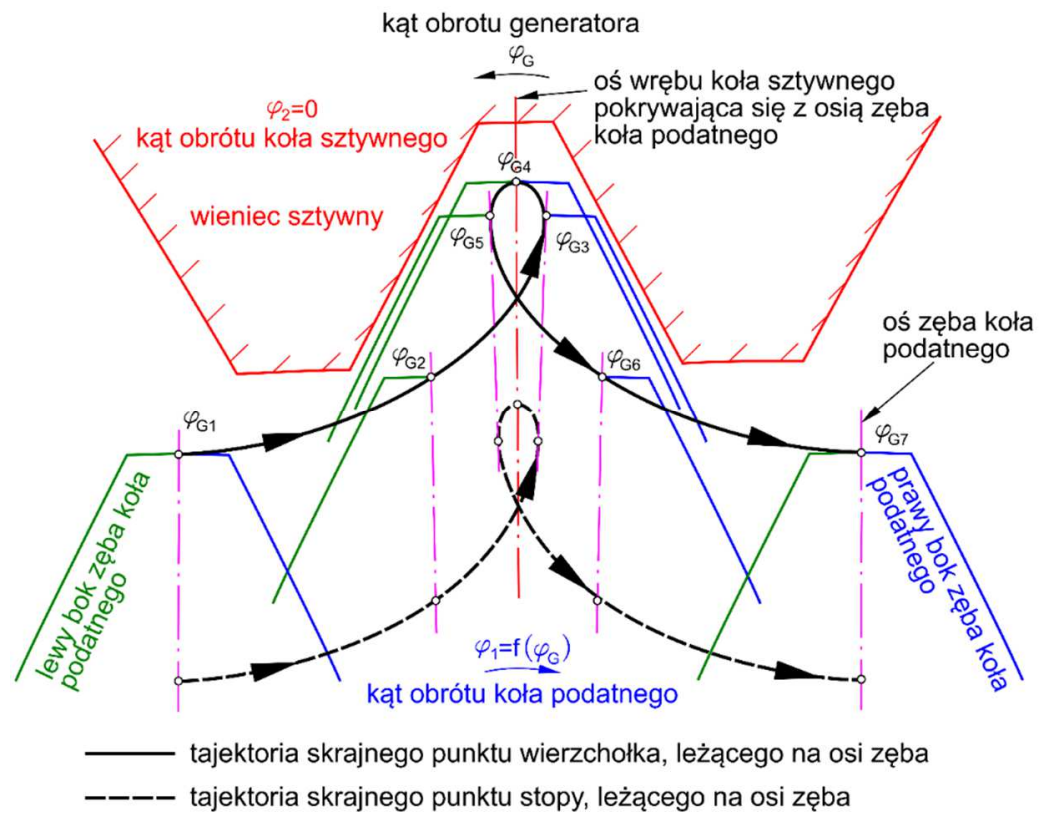

Rys. 1. Droga względna zęba koła podatnego

Fig. 1. Trajectory of flex spline tooth

\section{Definicja i metoda wyznaczania luzu obwodowego}

Podczas współpracy z wrębem koła sztywnego ząb koła podatnego obraca się oraz przemieszcza na kierunku promieniowym. W zależności od obciążenia przekładni, kształtu zarysu oraz trajektorii może dojść do współpracy lewego boku zęba koła podatnego tylko z lewym bokiem wrębu koła sztywnego lub lewego boku zęba koła podatnego z lewym bokiem wrębu koła sztywnego i prawego boku zęba koła podatnego z prawym bokiem wrębu koła sztywnego (rys. 1.).

Dla każdego kąta obrotu generatora $\varphi_{\mathrm{G}}$ oraz położenia zęba względem wrębu konieczne jest zatem zapewnienie odpowiedniej wartości luzu obwodowego $\widehat{J_{o}}$ po obu stronach osi zęba (rys. 2.). W przypadku przekładni nieobciążonej wartość 
luzu powinna być zawsze dodatnia. Dla przekładni obciążonej luz może być równy zeru lub większy. W pracy przyjęto, że luz obwodowy lewostronny $\widehat{J_{O L}}$ będzie łukiem opisanym przez promień $r_{y 2}$ i kąt $\Delta \varepsilon_{L}=\angle\left(A_{L}, O_{1}, B_{L}\right)$. Punkt $A_{L}$ leży na przecięciu okręgu o promieniu $r_{y 2} \mathrm{z}$ lewym zarysem wrębu koła sztywnego, $B_{L}$ - na przecięciu okręgu o promieniu $r_{y 2} \mathrm{z}$ lewym zarysem zęba koła podatnego (rys. 3.). Analogicznie jest definiowany luz prawostronny $\widehat{J_{O L}}$.

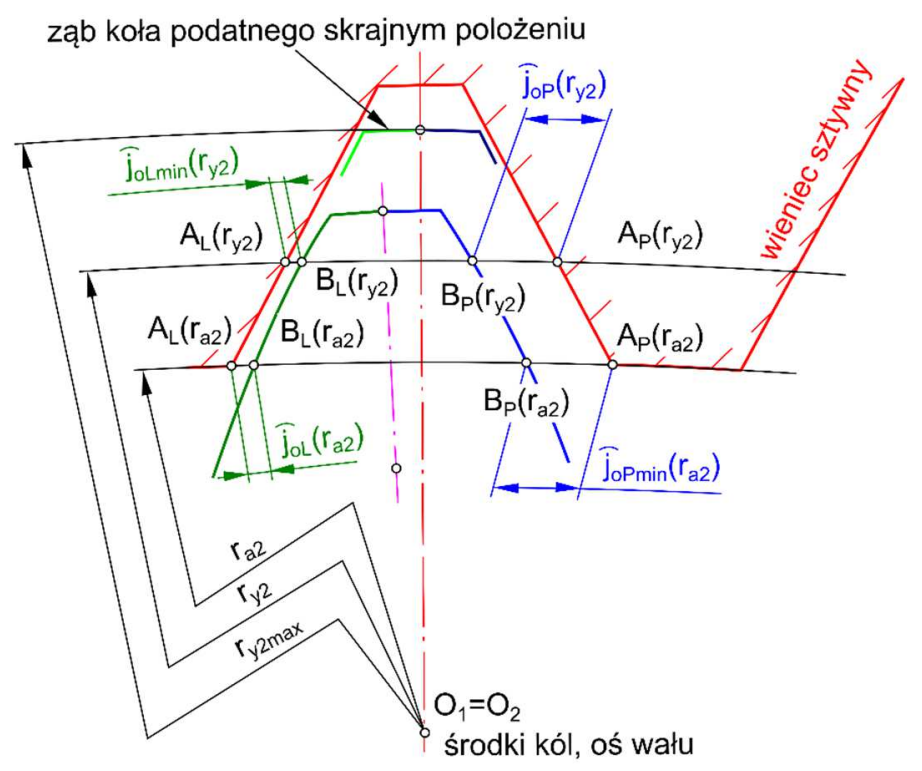

Rys. 2. Luzy obwodowe

Fig. 2. Side Backlashes

W celu zbadania współpracy zęba koła podatnego z wrębem koła sztywnego należy na całej czynnej wysokości zęba koła sztywnego $\left(r_{y 2}=r_{a 2}-r_{y 2 \max }\right)$ wyznaczyć luzy obwodowe $\widehat{\jmath_{o}} \mathrm{w}$ każdym położeniu generatora. W kolejnym etapie badań dla każdego położenia generatora ze zbioru wartości luzów obwodowych wyznaczono wartość minimalną.

$\mathrm{Na}$ rysunku 4. pokazano algorytm metody obliczeń luzów obwodowych: $\widehat{J_{O L}}$ - lewostronnego i $\widehat{J O P_{O P}}$ - prawostronnego. Luzy obwodowe $\widehat{J_{O L}}$ i $\widehat{J_{O P}}$ obliczano ze wzorów (1)-(4).

$$
\begin{aligned}
& \widehat{J_{O L}}=\Delta \varepsilon_{L} \cdot r_{y 2} \\
& \widehat{J_{O P}}=\Delta \varepsilon_{P} \cdot r_{y 2}
\end{aligned}
$$


gdzie:

$$
\begin{aligned}
& \Delta \varepsilon_{L}=\varepsilon_{2 L}-\varepsilon_{1 L}, r a d \\
& \Delta \varepsilon_{P}=\varepsilon_{1 P}-\varepsilon_{2 P}, r a d
\end{aligned}
$$

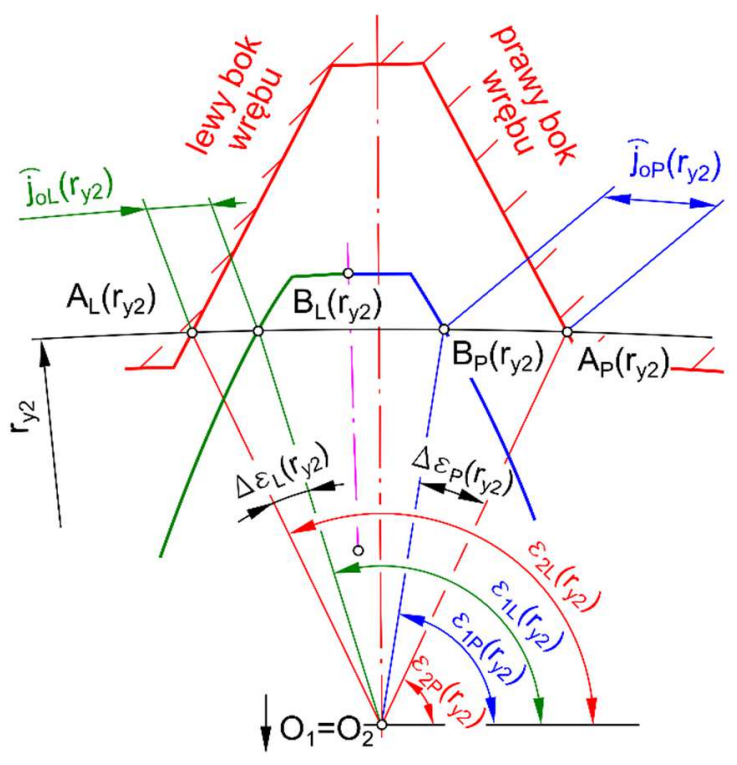

Rys. 3. Obliczanie luzów $\widehat{J O L}$ i $\widehat{J O P_{O P}}$, gdzie $\varepsilon$ - kąt zawarty między prostą przechodzącą przez punkt zarysu zęba (1) i wrębu (2) po lewej (L) lub prawej $(\mathrm{P})$ stronie; kąty $\varepsilon$ wyrażone w radianach

Fig. 3. Calculation of side backlashes, where: $\varepsilon$ - the angle between the line passing through the point of profile of flexspline's (1) and circular spline's tooth (2) from left (L) or right $(\mathrm{P})$ side; angles $\varepsilon$ are expressed in radians

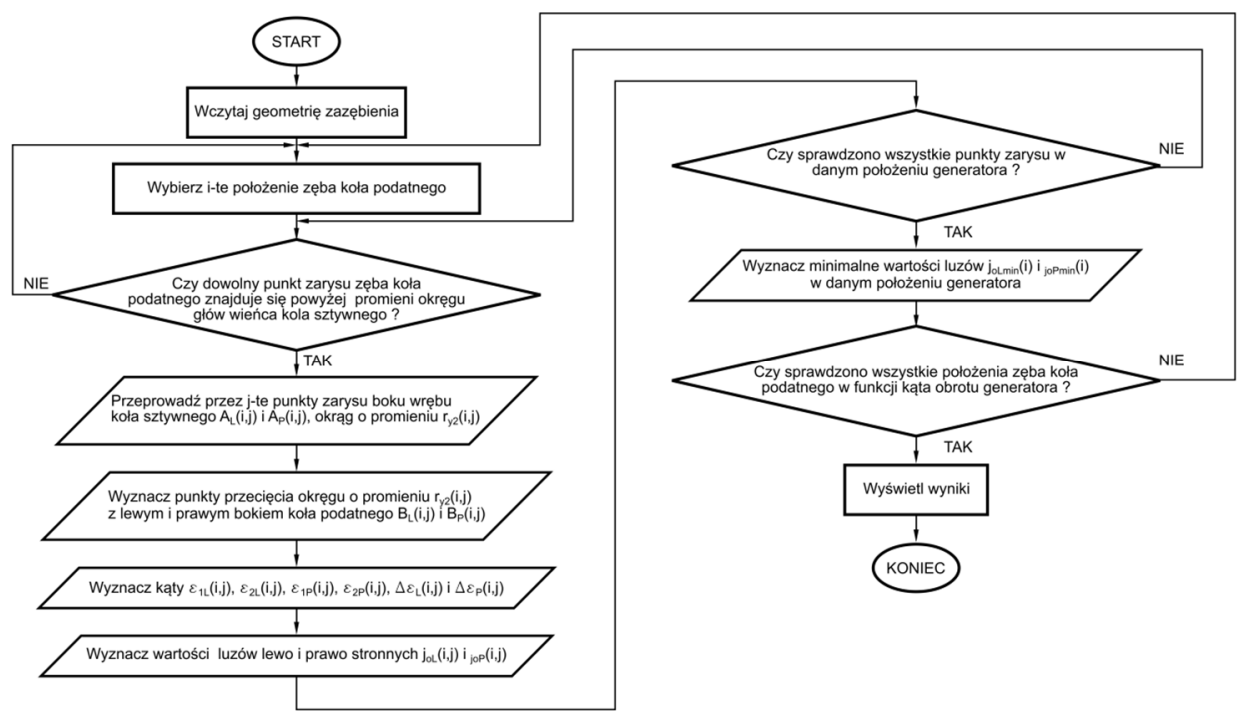

Rys. 4. Algorytm metody obliczania wartości luzów obwodowych

Fig. 4. Algorithm of the calculation method of side backlashes 


\section{Analiza wyników badań}

W tabeli 1. przedstawiono podstawowe parametry wieńców zębatych badanej przekładni falowej z generatorem krzywkowym. Do obliczeń przyjęto następujące założenia:

- wieniec koła sztywnego jest nieruchomy,

- w chwili początkowej dla kąta obrotu generatora $\varphi_{G}=0^{\circ}$, ząb koła podatnego znajduje się we wrębie koła sztywnego w skrajnym położeniu, oś wrębu pokrywa się z osią zęba,

- kąt obrotu generatora zmienia się w zakresie $\varphi_{G}=\left\langle-90^{\circ}, 0^{\circ}\right\rangle-$ ujemna wartość kąta wynika z tego, że generator obraca się w przeciwnym kierunku do kierunku obrotu wieńca podatnego,

- w przypadku gdy ząb koła podatnego znajduje się poniżej średnicy $d_{a 2}=2 r_{a 2}$, wartość luzu przyjmuje wartość $\widehat{J_{o}}=1$,

- obliczenia przeprowadzono dla 100 położeń generatora,

- do badań przyjęto tylko punkty leżące na bokach zęba i wrębu. Nie analizowano punktów opisujących łuk wierzchołka oraz dno wrębu,

- każdy bok (wrębu i zęba) podzielono na 110 punktów.

$\mathrm{W}$ wyniku przeprowadzonych badań otrzymano wartości luzów $\widehat{J_{O L}}$ i $\widehat{J_{O P}}$ $\mathrm{w}$ funkcji kąta obrotu generatora $\varphi_{G}$ oraz promienia $r_{y 2}$. Wartości tych luzów przedstawiono na rys. 5 . i 6 . Na rysunku 7. przedstawiono w powiększeniu uzyskane wartości luzów lewostronnych dla kąta obrotu generatora $\varphi_{G}=$ $=36,3636^{\circ}$. Na rysunku 8. przedstawiono wartości minimalnych luzów obwodowych lewo- i prawostronnych $\widehat{J_{O L} \min } \mathrm{i} \widehat{J_{O P} \min } \mathrm{w}$ funkcji obrotu generatora $\varphi_{G}$.

Tabela 1. Parametry geometryczne wieńców zębatych o zarysie ewolwentowym

Table 1. Geometrical parameters of gear rims with involute outline

\begin{tabular}{|c|c|c|c|}
\hline Wieniec & Parametr & Oznaczenie & Wartość \\
\hline \multirow{6}{*}{ 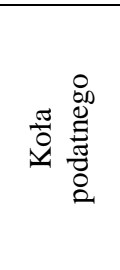 } & Promień okręgu podziałowego & $r_{1}$ & $39,6 \mathrm{~mm}$ \\
\hline & Promień okręgu stóp & $r_{f 1}$ & $40,824 \mathrm{~mm}$ \\
\hline & Promień okręgu głów & $r_{a 1}$ & $41,858 \mathrm{~mm}$ \\
\hline & Współczynnik przesunięcia zarysu & $x_{1}$ & 3,39 \\
\hline & Maksymalne odkształcenie promieniowe korpusu & $w_{0}$ & $0,64 \mathrm{~mm}$ \\
\hline & Promień nieodkształconej warstwy obojętnej & $R$ & $40,412 \mathrm{~mm}$ \\
\hline \multirow{4}{*}{ 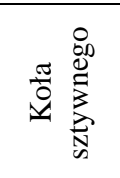 } & Promień okręgu podziałowego & $r_{2}$ & $40,2 \mathrm{~mm}$ \\
\hline & Promień okręgu stóp & $r_{f 2}$ & $42,7681 \mathrm{~mm}$ \\
\hline & Promień okręgu głów & $r_{a 2}$ & $41,658 \mathrm{~mm}$ \\
\hline & Współczynnik przesunięcia zarysu & $x_{2}$ & 3,55 \\
\hline
\end{tabular}




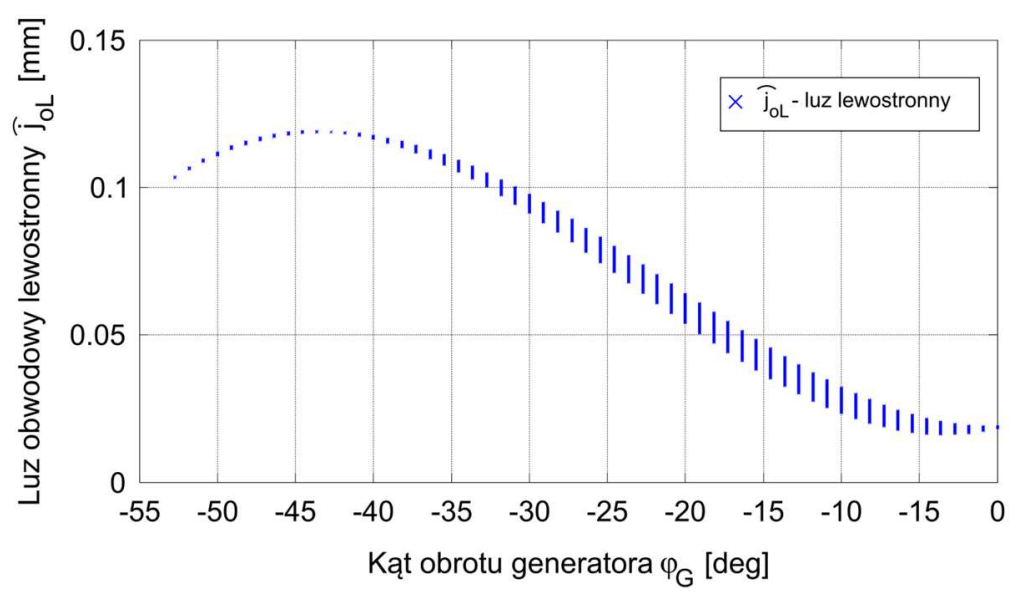

Rys. 5. Wartości luzu obwodowego lewostronnego $\widehat{J o L} \mathrm{w}$ funkcji kąta obrotu generatora $\varphi_{G}$ i promienia $r_{y 2}$

Fig. 5. Side backlash from the left side in the function of angle of rotation of wave generator $\varphi_{G}$ and radius $r_{y 2}$

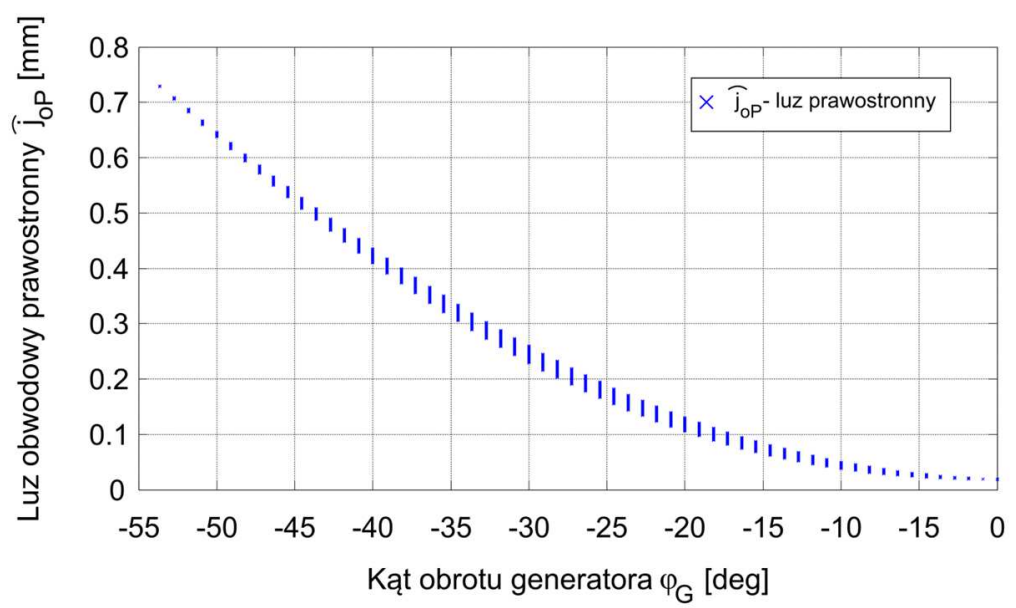

Rys. 6. Wartości luzu obwodowego prawostronnego $\widehat{O_{O P}}$ w funkcji kąta obrotu generatora $\varphi_{G}$ i promienia $r_{y 2}$

Fig. 6. Side backlash from the right side in the function of angle of rotation of wave generator $\varphi_{G}$ and radius $r_{y 2}$ 

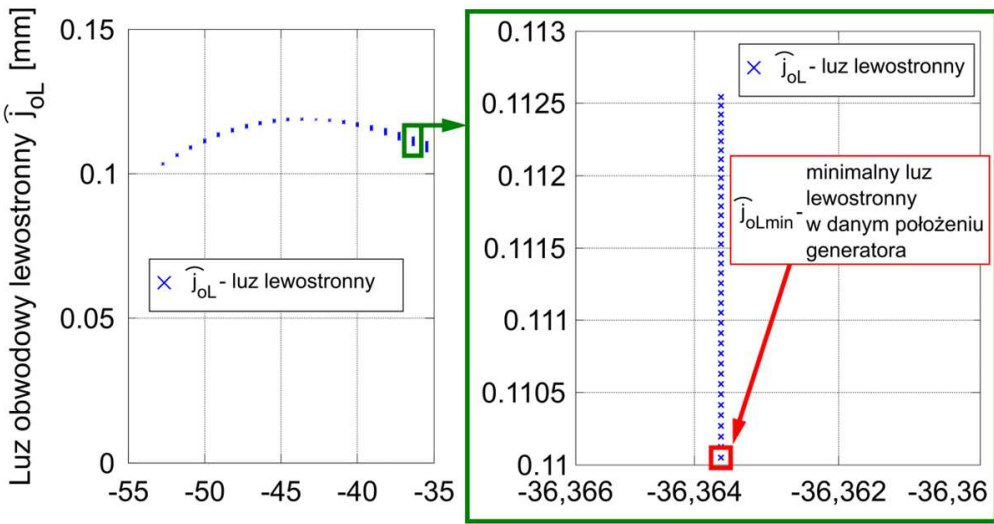

Kąt obrotu generatora $\varphi_{\mathrm{G}}[\mathrm{deg}]$

Rys. 7. Wartości luzu obwodowego lewostronnego $\widehat{J_{O L}} \mathrm{w}$ wybranym położeniu generatora oraz określenie luzu minimalnego $\widehat{O_{0 L}} \min \mathrm{W}$ tym położeniu

Fig. 7. Side backlash from the left side $\widehat{J_{O L}}$ in the selected position of wave generator and minimum value of side backlash from the left side $\widehat{J_{O L}} \min$ for this position of wave generator

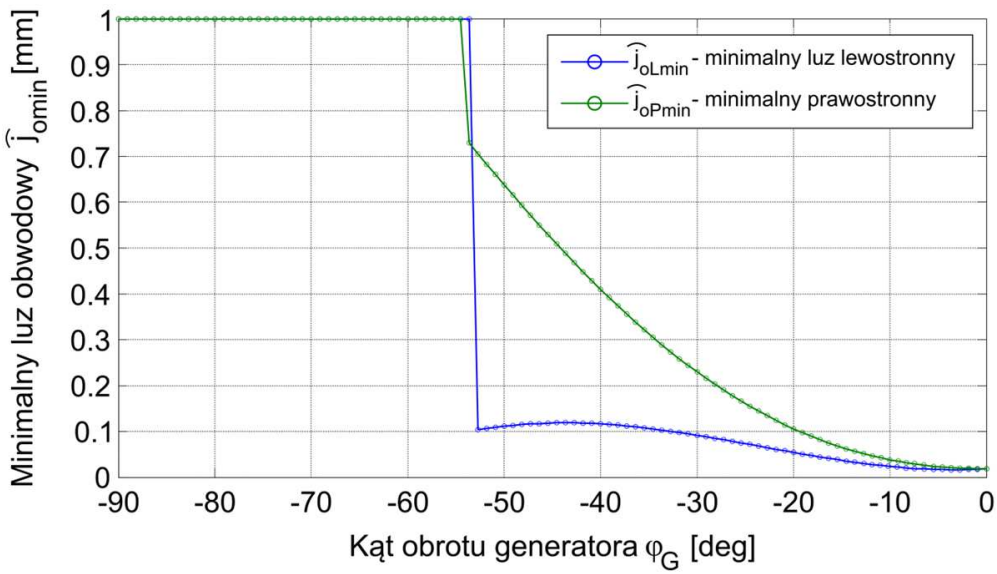

Rys. 8. Minimalne wartości luzów $\widehat{J_{O L}} \min \mathrm{i} \widehat{J_{O P}} \min \mathrm{w}$ funkcji kąta obrotu generatora $\varphi_{G}$

Fig. 8. Minimal values of side backlases $\widehat{J_{O L}} \min \mathrm{i} \widehat{J_{O P}} \min$ in the fuction of of the angle of rotation of wave generator $\varphi_{G}$ 


\section{Wnioski końcowe i podsumowanie}

Przeprowadzone symulacje komputerowe pozwalają na sformułowanie następujących wniosków:

- ząb koła podatnego wychodzi z przestrzeni wrębu międzyzębnego przy kącie $\varphi_{G} \approx-53,5^{\circ}$. Warto jednak zauważyć, że lewy bok zęba wyjdzie $\mathrm{z}$ tej przestrzeni wcześniej ze względu na pochylenie zęba koła podatnego w kierunku ruchu,

- najmniejsze wartości luzy obwodowe przyjmują dla kątów $\varphi_{G}=\left\langle-20^{\circ}, 0^{\circ}\right\rangle$,

- luz $\widehat{J O P} \min$ rośnie wraz ze wzrostem wartości bezwzględnej kąta obrotu generatora $\varphi_{G}$,

- luz $\widehat{J_{O L}} \min$ ma przebieg zbliżony do sinusoidy, przyjmując swoje maksi$\operatorname{mum} \max \left\{\widehat{\int_{o L} \min }\right\}=0,1183 \mathrm{~mm}$ dla $\varphi_{G} \approx-43^{\circ}$, z kolei minimum $\min \left\{\widehat{J_{O L} \min }\right\}=0,01639 \mathrm{~mm}$ dla kąta $\varphi_{G} \approx-3,64^{\circ}$,

- wartość luzu można modyfikować, zmieniając kształt zarysu zębów lub kształt krzywki. Zmienia się w tym przypadku wartość parametru $w_{0}$ lub funkcja opisująca geometrię krzywki.

\section{Literatura}

[1] Kalina A., Mazurkow A., Warchoł S.: Przegląd rozwiązań konstrukcyjnych przekładni falowych, Przegląd Mechaniczny, 2 (2017) 45-48.

[2] Mijał M.: Synteza falowych przekładni zębatych. Zagadnienia konstrukcyjno-technologiczne, OW PRz, Rzeszów 1999.

[3] Ostapski W.: Przekładnie falowe, OW Politechniki Warszawskiej, Warszawa 2011.

[4] Kalina A., Mazurkow A., Warchoł S.: Geometria zazębienia kół przekładni falowej, Stal Metale Nowe Technol., 1 (2018) 94-97.

[5] Kalina A., Mazurkow A., Warchoł S.: Trajektoria przemieszczeń zęba koła podatnego falowej przekładni z eliptycznym generatorem krzywkowym, Przegląd Mechaniczny, 11 (2017) 35-39.

\section{CALCULATION METHOD OF SIDE BACKLASH IN MESHING GEARS OF A HARMONIC GEAR}

\section{S u m m a r y}

The article contains information about the calculation method of side backlash for harmonic gear with involute profile. The first part of the paper contains a description of main geometric parameters of this kind of gear. After that a definition of side backlashes was defined with the main 
foundations of mathematical model of the method with algorithm. The summary contains conclusions. The presented method will be used in further research of tooth contact.

Keywords: wave transmission, meshing, rigid wheel, flexible wheel, circumferential play

DOI: $10.7862 / \mathrm{rm} .2018 .41$

Otrzymano/received: 27.03 .2018

Zaakceptowano/accepted: 25.10 .2018 
